\title{
A new subfamily of amaurobiid spiders (Aranei: Amaurobiidae) from West Caucasus
}

\author{
Новое подсемейство амауробиидных пауков (Aranei: \\ Amaurobiidae) с Западного Кавказа
}

\author{
Yuri M. Marusik ${ }^{1,2}$, Mykola M. Kovblyuk ${ }^{3}$ \\ and Aleksandr V. Ponomarev ${ }^{4}$ \\ Ю.М. Марусик ${ }^{1,2}$, Н.М. Ковблюк ${ }^{3}$, А.В. Пономарёв ${ }^{4}$
}

\footnotetext{
${ }^{1}$ Institute for Biological Problems of the North, RAS, Portovaya Str. 18, Magadan 685000, Russia. E-mail: yurmar@mail.ru ИБПС ДВО РАН, Портовая 18, Магадан 685000.

${ }^{2}$ Zoological Museum, University of Turku, FI-20014 Turku, Finland.

3 Zoology Department, V.I. Vernadsky Taurida National University, Yaltinskaya Street 4, Simferopol 95007, Ukraine. E-mail: kovblyuk@mail.ru

Кафедра зоологии Таврического национального университета им. В.И.Вернадского, ул. Ялтинская 4, Симферополь 95007, Украина. ${ }^{4}$ South Scientific Centre RAS, Chekhov Str., 41, Rostov-on-Don 344006 Russia. E-mail: ponomarev1952@mail.ru Южный научный центр РАН, пр. Чехова, 41, Ростов-на-Дону 344006 Россия.
}

KEY WORDS: RTA-clade, Amaurobioidea, new genus, new species, Russia.

КЛЮЧЕВЫЕ СЛОВА: RTА-клада, Amaurobioidea, новый род, новый вид, Россия.

ABSTRACT: A new ecribellate subfamily Ovtchinnikoviinae subfam.n. of Amaurobiidae has been described on the basis of Ovtchinnikovia caucasica gen.n. et sp.n. This group is characterized by a serrated keel on inner side of the cheliceral groove, lack of cribellum and lateral epigynal teeth, presence of feathery hairs and shape of copulatory organs.

РЕЗЮМЕ: В составе семейства Amaurobiidae описано новое экрибеллятное подсемейство Ovtchinnikoviinae subfam.n. Подсемейство включает новый род и вид Ovtchinnikovia caucasica gen.n. et sp.n. Новое подсемейство характеризуется зубчатым килем на внутренней поверхности хелицер, отсутствием крибеллюма и зубчиков эпигины, наличием перовидных волосков и своеобразной формой копулятивных органов.

\section{Introduction}

Amaurobiidae Thorell, 1870, is large globally distributed family with 874 species placed in 75 genera [Platnick, 2010]. Five subfamilies are recognized in this group: Altellopsinae, Amaurobiinae, Arctobiinae, Coelotinae, Macrobuninae and Midgeeinae [Jocqué \& Dippenaar-Schoeman, 2006]. The most speciose subfamily, Coelotinae, with some 589 species in 23 genera [Wang, 2010] distributed exclusively in the Holarctic, seems to belong to Agelenidae [Lehtinen, 1967; Miller et al., 2010] or to a family of its own [cf. Nishikawa,
2009]. The family is still poorly defined and lacks distinct apomorphies [Jocqué \& Dippenaar-Schoeman, 2006]. The same is true for most of families recently established for former amaurobiid subfamilies such as Amphinectidae, Desidae and Stiphididae.

West Palaearctic amaurobiids belong in three subfamilies: Coelotinae (about 50 species in 4 genera), Amaurobiinae (Amaurobius - 37 species and Callobius - 1 species) and Arctobiinae (Arctobius, monotypic genus). All West Palaearctic taxa are fairly well studied.

While identifying spiders from the North Caucasus we found one species belonging to an RTA clade that was impossible to place in any genus and even family because of its unusual characters in somatic morphology, and in shape of the copulatory organs. Comparison with all possible families led us to conclusion that it represent new species and genus and can be placed as a separate subfamily of Amaurobiidae.

\section{Methods}

All specimens have been collected in south part of Krasnodar Province by means of hand picking and pitfall trapping. Specimens were photographed using an Olympus Camedia C-520 camera attached to an Olympus SZX16 stereomicroscope. The images were combined using "CombineZP" image stacking software. Photographs were taken in dishes of different sizes, with paraffin at the bottom. Holes of different sizes were made in the paraffin to keep the specimens 

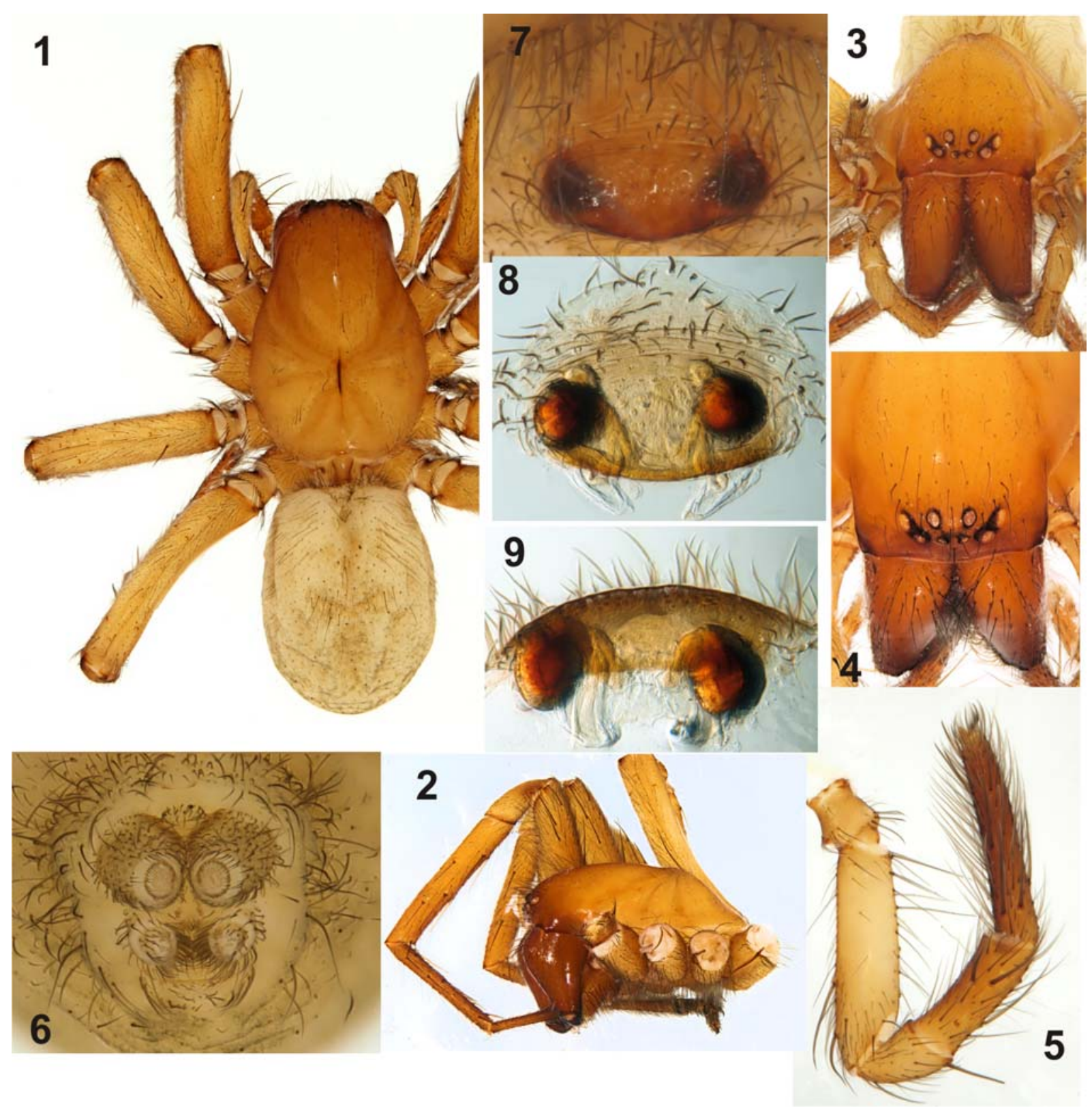

Figs 1-9. Female of Ovtchinnikovia caucasica sp.n.: 1 - habitus, dorsal; $2-3$ - prosoma lateral and frontal; 4 - cephalic part, dorso-frontal; 5 - palp, lateral; 7 - intact epigyne, ventral; 8 - epigyne after maceration, ventral; 9 - epigyne after maceration, caudal.

Рис. 1-9. Самка Ovtchinnikovia caucasica sp.n.: 1 - габитус, дорсально; 2-3 - головогрудь, сбоку и спереди; 4 - головной отдел, сверху-спереди; 5 - пальпа, сбоку; 7 - эпигина не вырезанная, вентрально; 8 - эпигина после мацерации, вентрально; 9 - эпигина после мацерации, сзади.

in the correct position. Scanning electron micrographs were made using the JEOL JSM-5200 scanning electron microscope at the Zoological Museum, University of Turku. SEM micrographs were made from a specimen from Krasnaya Polyana, and all other illustrations are based on specimens from the Caucasian Biosphere Reserve. All measurements are given in $\mathrm{mm}$.

Abbreviations for museums: $\mathrm{CP}$ - personal collection of A.V. Ponomarev; JWC - personal collection of J. Wunderlich; SOPC - personal collection of late Sergei Ovtchinnikov, temporary in Almaty (Kazakhstan) under care of A. Gromov; ZMMU - Zoological Museum of the Moscow State University.

Abbreviations in the text: AME, ALE, PME and PLE - anterior median, anterior lateral, posterior median and posterior lateral eyes respectively; a, d, p, r, $\mathrm{v}$ - apical, dorsal, prolateral, retrolateral, ventral leg spines. 

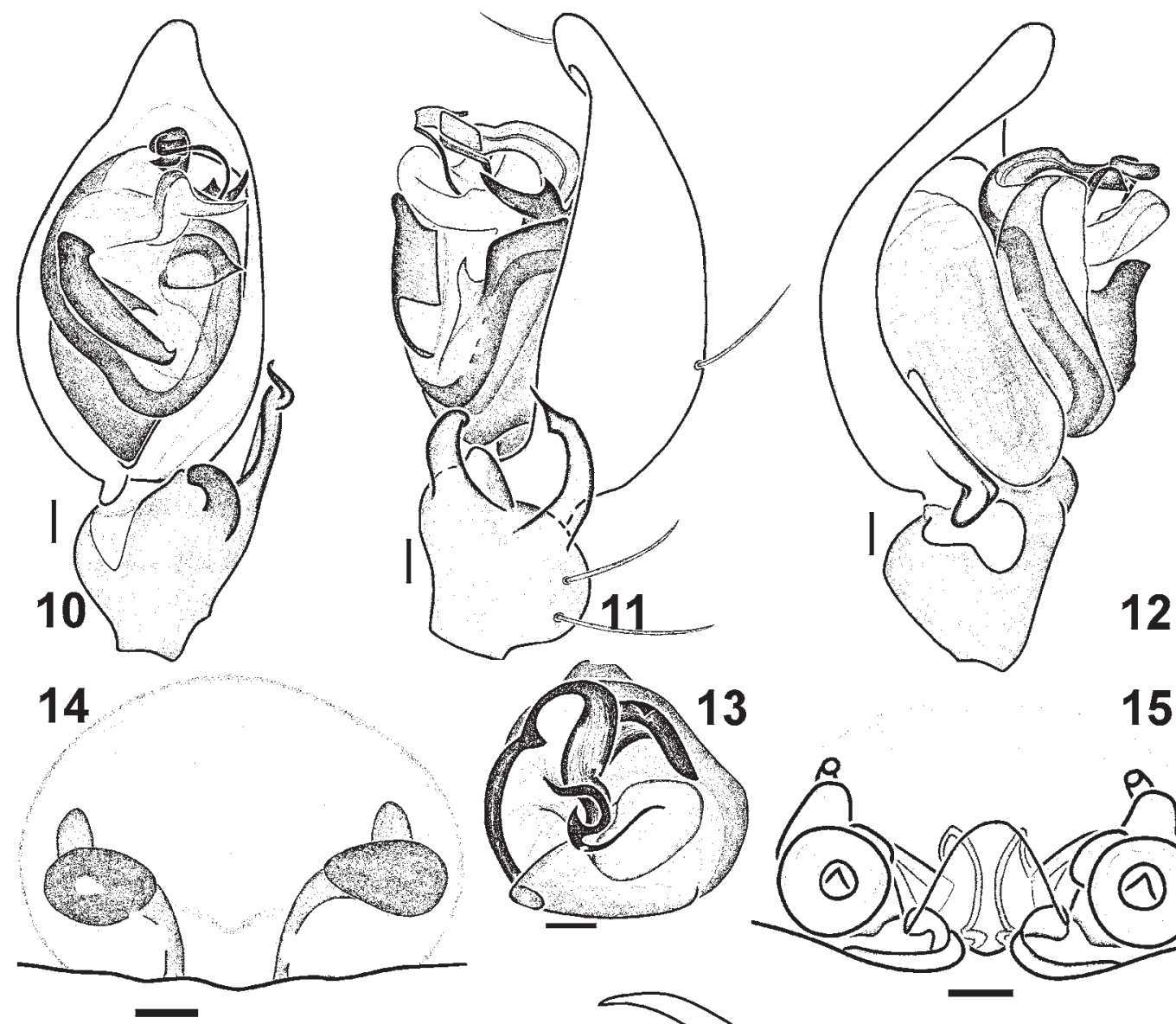

$3 \quad 15$
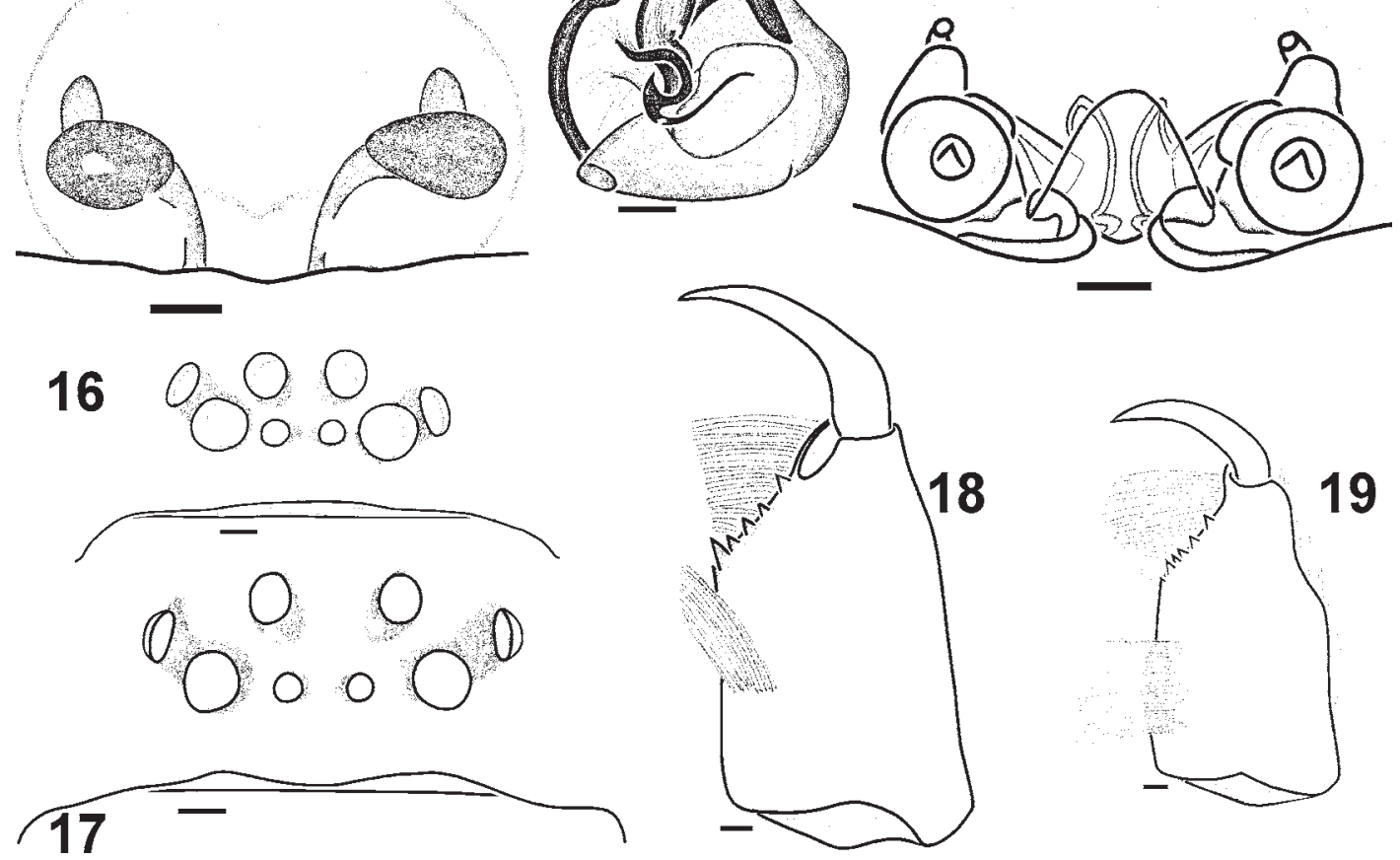

Figs 10-19. Copulatory organs, eyes and chelicera of Ovtchinnikovia caucasica sp.n.: 10-12 - left male palp, ventral, retrolateral and prolateral; 13 - bulbus, terminal; 14-15 - epigyne, ventral and dorsal; 16-17 - ocular area of male and female, frontal; 18-19 chelicera of male and female, posterior view. Scale $0.1 \mathrm{~mm}$.

Рис. 10-19. Копулятивные органы, глаза и хелицеры Ovtchinnikovia caucasica sp.n.: 10-12 — левая пальпа самца, вентрально, ретролатерально и пролатерально; 13 - бульбус, терминально; 14-15 - эпигина, вентрально и дорсально; 16-17 — глазное поле самца и самки, вид спереди; 18-19- хелицеры самца и самки, сзади. Масштаб 0,1 мм.

\section{Taxonomic survey}

Ovtchinnikoviinae subfam.n.

DIAGNOSIS. From all amaurobioid families and amaurobiid subfamilies differs by having a serrated keel on inner margin of the cheliceral groove, prolateral position of the tegular apophysis, a complicated embolus bent 3 times, filamentous on the tip, with two apophyses in its base, and a solid epigynal plate with insemination opening in epigastric fold.

Habitually similar ecribellate Coelotinae (Coelotidae sensu Nishikawa [2009]) differs from Ovtchinnikovii- 

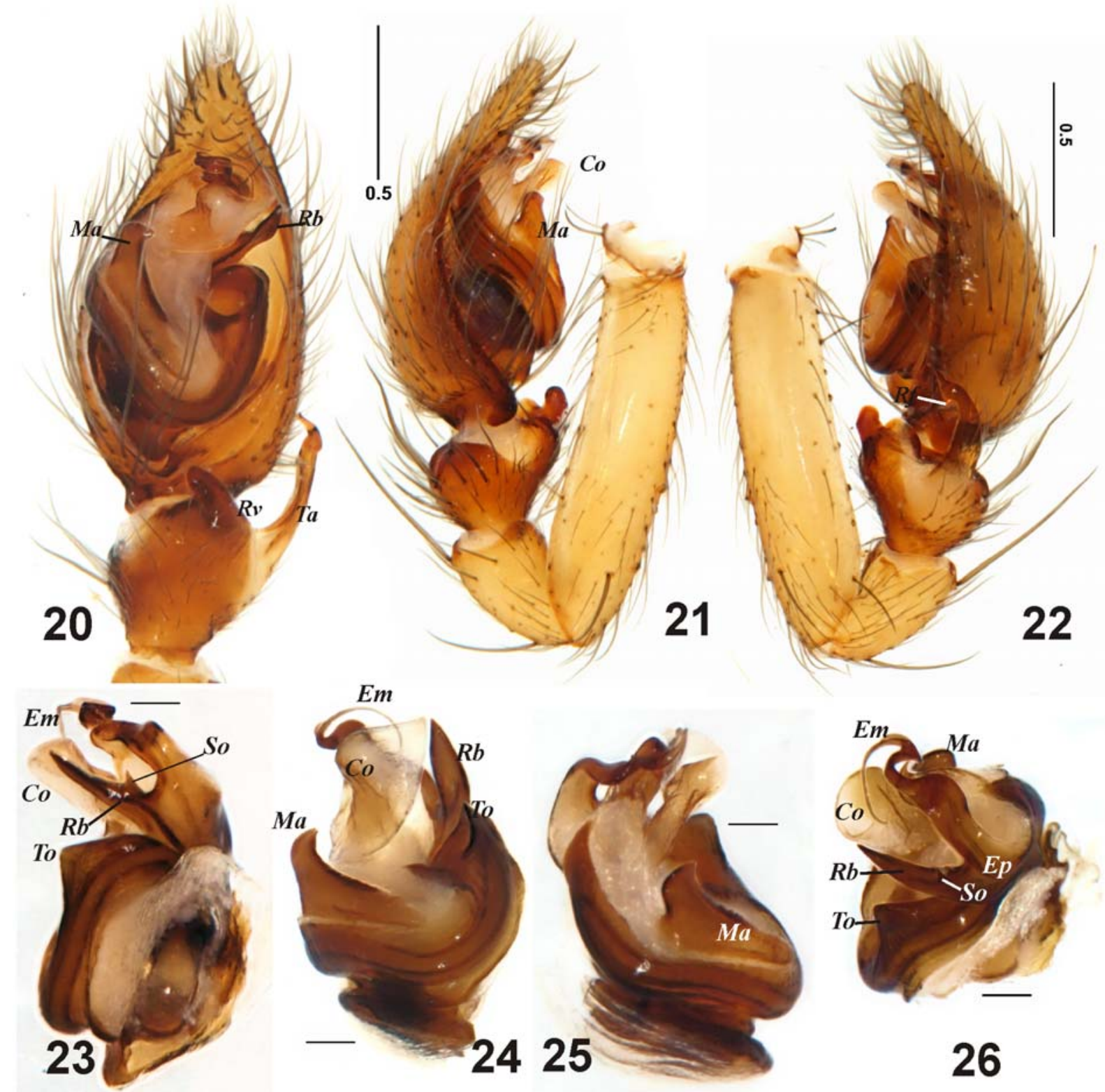

Figs 20-26. Left male palp of Ovtchinnikovia caucasica sp.n.: 20-22 - whole male palp, ventral, prolateral and retrolateral; 23 bulbus, retrolateral; 24 - bulbus, subcaudal; 25 - bulbus, prolateral; 26 - bulbus, dorso-retrolateral. Scale $0.1 \mathrm{~mm}$ if not otherwise indicated.

Abbreviations: $C o$ - conductor; $E m$ - embolus proper; $E p$ - embolic part; $M a$ - median apophysis; $R b$ - basal retrolateral apophysis of embolic division; $R f$ - retrolateral cymbial fold; $R v$ - retroventral tibial apophysis; So - spine like outgrowth; Ta retrolateral tibial apophysis; To - triangular retrolateral outgrowth of the tegulum.

Рис. 20-26. Левая пальпа самца Ovtchinnikovia caucasica sp.n.: 20-22 - целая пальпа, вентрально, пролатерально и ретролатерально; 23 - бульбус, ретролатерально; 24 - бульбус, немного сзади; 25 - бульбус, пролатерально; 26 - бульбус, ретролатерально-дорсально. Масштаб 0,1 мм, если не указано иное значение.

Обозначения: $C o$ - кондуктор; $E m$ - эмболюс; $E p$ - эмболярный отдел бульбуса; $M a$ - срединный отросток бульбуса; $R b-$ основной ретролатеральный отросток эмболярного отдела; $R f$ - ретролатеральная складка цимбиума; $R v-$ ретро-вентральный отросток голени; So - шиповидный вырост; $T a$ - ретролатеральный отросток голени; $T o$ - треугольный ретролатеральный вырост тегулюма.

nae subfam. $n$. by having elongated spinnerets, lack of a serrated keel on the cheliceral retromargin, feathery hairs, and different copulatory organs. Amaurobiinae, Macrobuninae and Arctobiinae differ from Ovtchinnikoviinae subfam.n. in having a cribellum and a calam- istrum, lack of a serrated cheliceral keel and feathery hairs, and the shape of the copulatory organs. Altellopsinae is entirely a Neotropical subfamily, Macrobuninae is a New World taxon, and Midgeeinae is exclusively an Australian group. None of these groups, as 

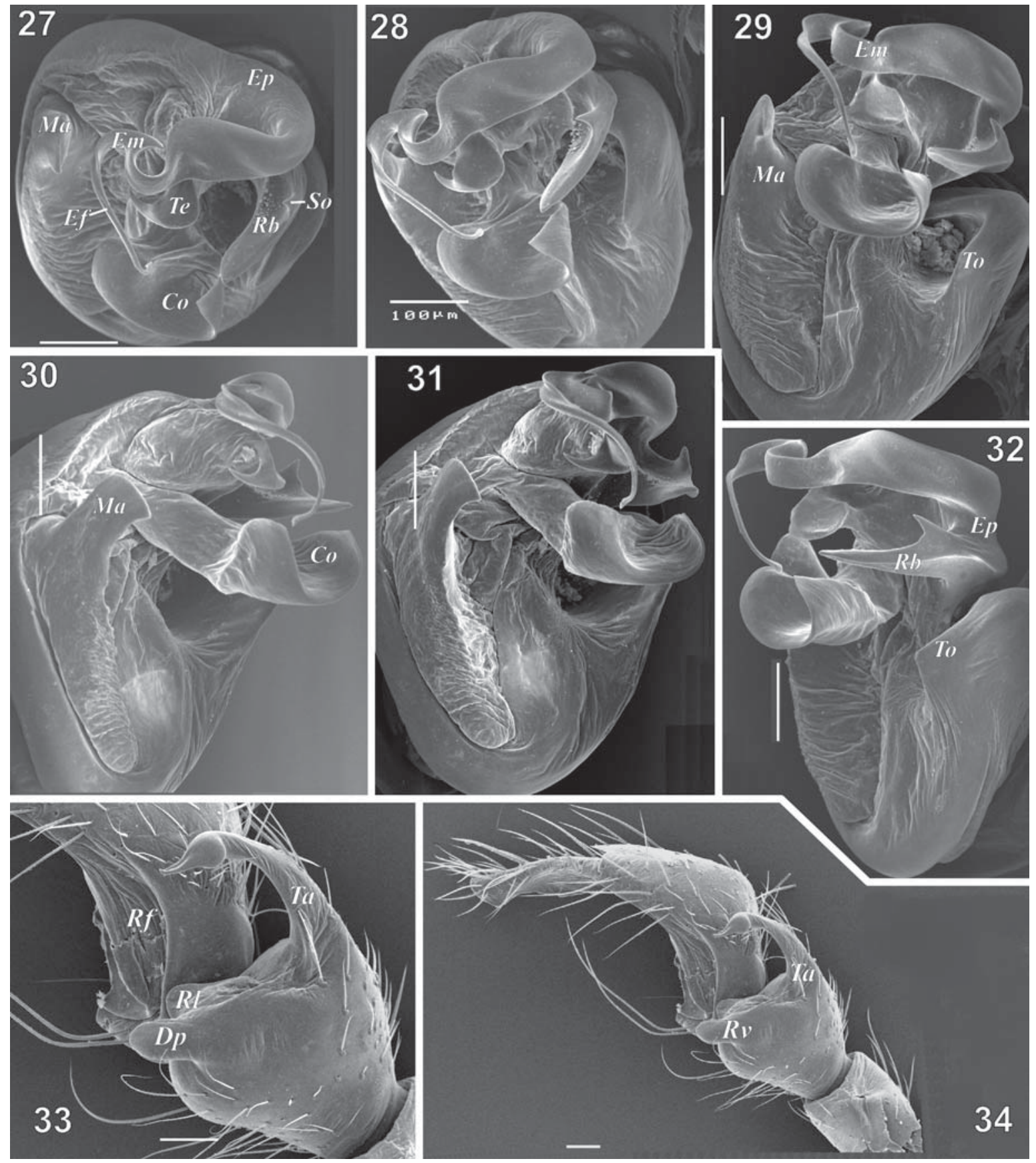

Figs 27-34. SEM micgrorgraphs of the left male palp of Ovtchinnikovia cancasica sp.n.: 27 - bulbus, terminal; 28 - bulbus, terminal-retrolateral; 29 - bulbus, ventral; 30-31 - bulbus, prolateral-terminal, different angles; 32 - bulbus, ventro-retrolateral; 33 tibia and part of cymbium, retrolateral; 34 - palp with removed bulbus, retrolateral. Scale $0.1 \mathrm{~mm}$.

Abbreviations: $C o$ - conductor; $D p$ - digitiform process; $E f$ - filamentous tip of embolus; $E m$ - embolus proper; $E p$ - embolic part; $M a$ - median apophysis; $R b$ - basal retrolateral apophysis of embolic division; $R f$ - retrolateral cymbial fold; $R l$ - rounded lobe; $R v$ - retroventral tibial apophysis; So - spine like outgrowth; $T a$ - retrolateral tibial apophysis; $T e$ - terminal apophysis; $T o-$ triangular retrolateral outgrowth of the tegulum.

Рис. 27-34. СЭМ-фотографии левой пальпы самца Ovtchinnikovia caucasica sp.n.: 27 - бульбус терминально; 28 - бульбус, терминально-ретролатерально; 29 - бульбус, вентрально; 30-31 - бульбус, пролатерально-терминально, немного разные ракурсы; 32 - бульбус, вентро-ретролатерально; 33 - голень и часть цимбиума, ретролатерально; 34 - пальпа с удалённым бульбусом, ретролатерально. Масштаб 0,1 мм.

Обозначения: $C o$ - кондуктор; $D p$ - пальцевидный вырост; $E f$ - нитевидный конец эмболюса; $E m$ - собственно эмболюс; $E p$ - эмболярный отдел; $M a$ - срединный отросток; $R b$ - ретролатеральный отросток основания эмболярного отдела; $R f-$ ретролатеральная складка цимбиума; $R l$ - округлая лопасть; $R v$ - ретро-вентральный отросток голени; So - шиповидный вырост; $T a$ - ретролатеральный отросток голени; $T e$ - терминальный отросток; $T o-$ треугольный ретролатеральный вырост тегулюма. 
well as three subfamilies of Amphinectidae (a family somewhat similar to Ovtchinnikoviinae subfam.n): Amphinectinae, Metaltellinae and Tasmarubriinae, has a serrated keel on the chelicera.

RELATIONSHIPS. Ovchinnikoviinae subfam.n. can be equally placed in Amaurobiidae or Amphinectidae (poorly diagnosed austral family, earlier placed in subfamily Desinae within Amaurobiidae). Now Desidae is treated as a separate family; it has copulatory organs very different from those of Amaurobius C.L. Koch, 1837 and Amphinecta Simon, 1898.

\section{Ovtchinnikovia gen.n.}

Type species: Ovtchinnikovia caucasica sp.n.

ETYMOLOGY. The genus is named after our late colleague and friend Sergei V. Ovchinnikov who first collected this genus and pointed us to its unclear belonging. The gender is feminine.

DIAGNOSIS. Same as for the subfamily.

DESCRIPTION. Same as for species.

COMMENTS. The palp is very complicated in comparison to a very simple epigyne.

Spinnerets in male. Anterior spinnerets (Figs 4344) with about 28 piriform gland spigots and one major ampullate gland spigot with nubbin $(?, \mathrm{Nu})$ near its base. Second ampullate spigot probably poorly visible if present or absent. Median spinnerets small (Figs 43, 48) with five gland spigots, four aciniform and one presumably minor ampullate which are on a large base. Posterior spinnerets (Figs 43, 47) with 18 aciniform gland spigots. Colulus (Figs 45-46) large, pentagonal with about 16 setae.

General assemblage (relative size, number of spigots) of spinnerets is similar to those in several cribellate taxa belonging to four families: Phryganoporus candidus (L. Koch, 1872) (Desidae), Neoramia nana Forster \& Wilton, 1973 (Agelenidae), Phyxelida tanganensis (Simon \& Fage, 1922) (Phyxelididae), Maniho ngaitahu Forster \& Wilton, 1973 (Amphinectidae) and also to ecribellate amaurobid Macrobunus multidentatus (Tullgren, 1902) [cf. Griswold et al., 2005].

Trichobothria. Trichobothrial base in Ovtchinnikovia gen.n. (Fig. 38) is similar to those in Vytfutia Deeleman-Reinhold, 1986 (Phyxelididae) and titanoecids Goeldia Keyserling, 1891, Titanoeca Thorell, 1870 [cf. Griswold et al., 2005] by having four strong ridges on the upper half of the base and smooth in basal half with fine circular cuticular wrinkles. All these three genera have a cribellum and much simpler copulatory organs. Amaurobius has also somewhat similar trichobothrial base, but cuticular wrinkles of the basal half are radial, not circular.

\section{Ovtchinnikovia caucasica sp.n.}

Figs 1-48.

Cybaeus ? sp.: Ponomarev \& Chumachenko, 2007: 155. TYPE MATERIAL. Holotype $\sigma^{7}$ (ZMMU), RUSSIA, Krasnodar Prov., Sochi, Khosta, Caucasian Biosphere Reserve, Taxus
Buxus forest, pitfalls, September 2006 (Y.A. Chumachenko). Paratypes: $2 \mathrm{O}^{\top} \mathrm{O}^{7}$ (CP: 47.10.1/1), Krasnodar Prov., Sochi, Khosta, Caucasian Biosphere Reserve $\left(44-44.5^{\circ} \mathrm{N}\right.$ and $\left.40-41^{\circ} \mathrm{E}\right)$, TaxusBuxus forest, yew-beech stand, 08.2006 (Y.A. Chumachenko); 1 ㅇ (CP: 47.10.1/2), same locality, beech stand, 04.2006 (Y.A. Chumachenko); $51 \Im^{7} \sigma^{\top}, 3$ 우 (CP: 47.10.1/3), same locality, yew-box stand, March-October 2006 (Y.A. Chumachenko); 8 ○ $\sigma^{\top}, 4$ 우 (ZMMU), same locality, March-October 2006 (Y.A. Chumachenko); 1 O (JWC), same locality, September 2006 (Y.A. Chumachenko). ADDITIONAL MATERIAL: 1 \% (SOPC), Krasnodar Prov., Krasnaya Polyana, no exact data (S.V. Ovtchinnikov).

ETYMOLOGY. Specific name derived from the type locality "Caucasus".

DIAGNOSIS. Same as in subfamily. Even juvenile specimens of this species can be easily recognized because of the serrated keel on inner side of the cheliceral groove.

DESCRIPTION. Male. Total length 6.0. Carapace 2.9 (2.7-3.4) long, 2.1 wide. Abdomen 2.4 long, 1.9 wide. Carapace domed, light brown without pattern, with darker fovea and eye field. AME 0.08, ALE 0.18, PME 0.16, PLE 0.18, AME-AME 0.08, AME-ALE 0.04, AME-PME 0.08, ALE-PLE 0.03; PME-PME 0.09; PME-PLE 0.14. AME lack (or reduced) in some males. Clypeus low, subequal to ALE diameter. Sternum shield-like, pointed, colored as carapace and lacks pattern. Maxillae and labium rectangular. Coxae IV (not spaced) touching. Chelicerae geniculate, with 6 teeth and dense brush of filtration setae $(F S)$ on promarginal side and serrated keel $(S k)$ on the retromarginal side (Figs 36-37). Keel with about a dozen teeth. Legs light yellow brown without rings, trochanters notched, with numerous spines, tarsi with three claws, all claws with teeth. Scopula and claw tufts absent. Tarsi with three rows of trichobothria, dorsal trichobothria increasing length distally; metatarsi and tibia with 4 rows of trichobothria; each row with about 5-7 trichobothria. Feathery hairs present $(F h)$ on legs and carapace (Fig. 39). Spination is shown in the table. Number of spines variable, especially on dorsal, proand retrolateral sides.

Abdomen light yellow-brown including spinnerets and book lungs, without pattern. Colulus large, pentagonal, with some 10-11 setae on the perimeter of base, and 5-7 irregularly placed on colulus proper (Fig. 46).

Leg joint length

\begin{tabular}{|l|c|c|c|c|c|c|}
\hline leg & Femur & Patella & Tibia & Metatarsus & Tarsus & Total \\
\hline I & 2.6 & 1.0 & 2.3 & 2.0 & 1.3 & 9.2 \\
\hline II & 2.5 & 1.0 & 2.0 & 2.0 & 1.2 & 8.7 \\
\hline III & 2.2 & 0.9 & 1.6 & 2.0 & 1.1 & 7.8 \\
\hline IV & 2.9 & 1.0 & 2.6 & 2.9 & 1.4 & 10.8 \\
\hline
\end{tabular}

Leg spination

\begin{tabular}{|c|c|c|c|c|}
\hline & Femur & Patella & Tibia & Metatarsus \\
\hline I & $\begin{array}{c}\mathrm{d} 1-1, \mathrm{p} 1-1-1, \\
\mathrm{r} 1-1-1\end{array}$ & 0 & $\begin{array}{l}\text { p 1-1, r } 1, \\
\text { v 2-2-2a }\end{array}$ & $\begin{array}{l}\text { p } 1-1-1, \\
\text { v 2-2-2a }\end{array}$ \\
\hline II & $\begin{array}{c}\text { d 1-1, p 1-1-1, } \\
\text { r 1-1 }\end{array}$ & 0 & $\begin{array}{l}\text { p 1-1, r 1, } \\
\text { v 2-2-2a }\end{array}$ & $\begin{array}{c}\text { p } 1-2, \text { r } 0-2 \text {, } \\
\text { v 2-2-1a }\end{array}$ \\
\hline III & $\begin{array}{c}\text { d } 1-1, \mathrm{p} 1-1-1 \\
\text { r } 1-1-1\end{array}$ & r 1 & $\begin{array}{c}\text { d 1, p 1-1-1, } \\
\text { r } 1-1-1, \\
\text { v } 2-2-2 \mathrm{a}\end{array}$ & $\begin{array}{l}\text { p 1-2-2, } \\
\text { r } 1-1-2, \\
\text { v } 2-2-1 a\end{array}$ \\
\hline IV & $\begin{array}{c}\mathrm{d} 1-1-1, \mathrm{p} 1-1 \\
\mathrm{r} 1\end{array}$ & 0 & $\begin{array}{c}\mathrm{d} 1-1, \mathrm{p} 1-1-1, \\
\text { r } 1-1-1, \\
\text { v } 2-2-2 \mathrm{a}\end{array}$ & $\begin{array}{l}\text { p 1-2-2, } \\
\text { r 1-1-2, } \\
\text { v 2-2-1a }\end{array}$ \\
\hline
\end{tabular}



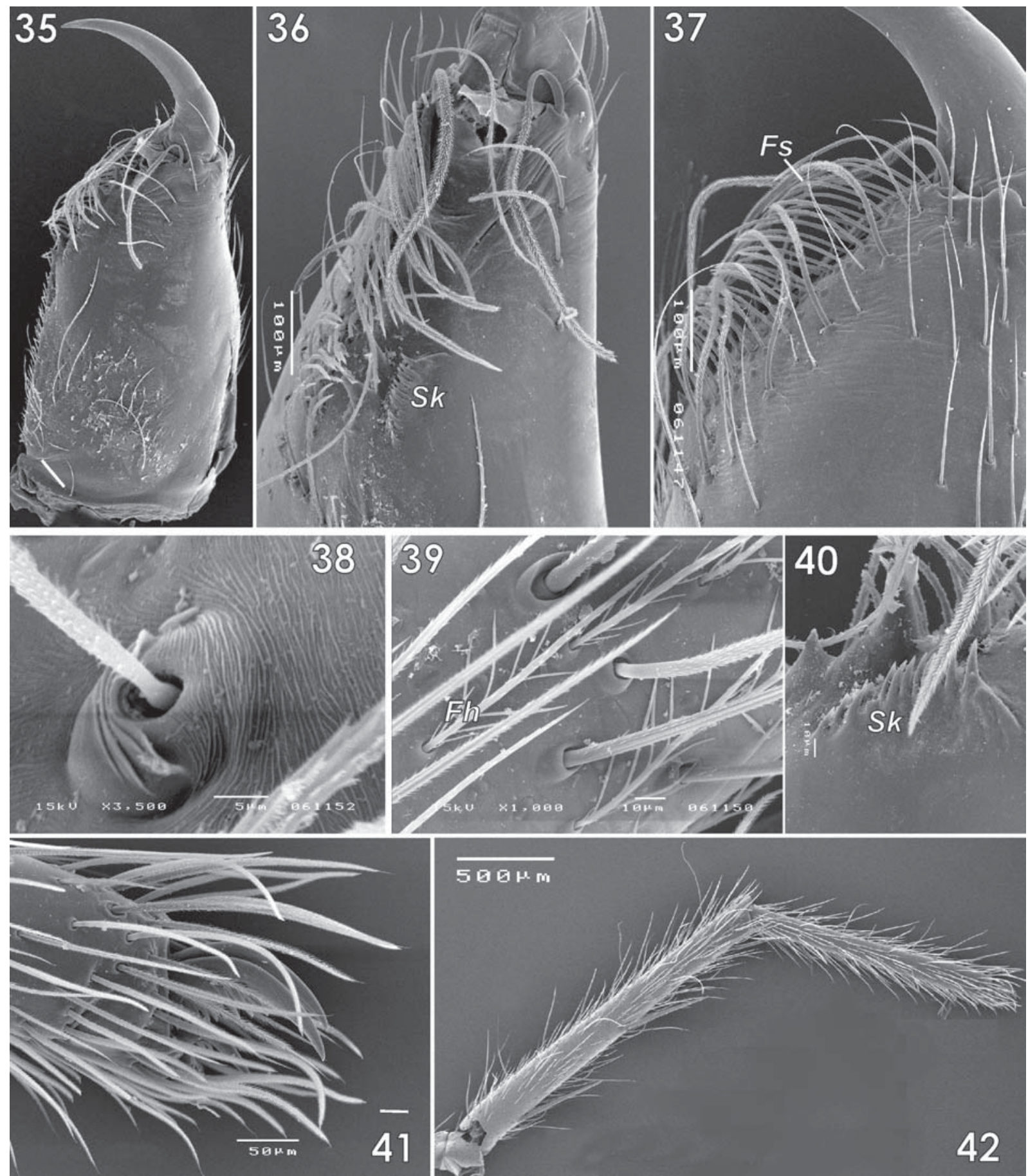

Figs 35-42. SEM micgrorgraphs of the male Ovtchinnikovia caucasica sp.n.: 35 - male chelicera, inner view; 36 - terminal part of chelicera showing groove and serrated keel; 37 - terminal part of chelicera, frontal, showing dense filtration setae; 38 - base of trichobothrium with four ridges in the upper half and fine cuticular wrinkles on the down half; 39 - feathery hairs on leg I; 40 - serrated keel on cheliceral retromargin and two teeth on promargin; 41 - tip of tarsus I; 42 - metatarsus and tarsus of leg I, prolateral.

Abbreviations: $F s$ - filtration setae; $F h$ - feathery hairs; $S k$ — serrated keel.

Рис. 35-42. СЭМ-фотографии самца Ovtchinnikovia caucasica sp.n. из Красной Поляны: 35 - хелицера, с внутренней стороны; 36 - терминальная часть хелицеры, видно желобок и зазубренный киль; 37 - терминальная часть хелицеры, спереди, видно зазубренные фильтруюшие шетинки; 38 - основание трихоботрии с четырьмя гребнями в верхней части и чёткими складками кутикулы в нижней части; 39 - перовидные волоски на ноге I; 40 - зубчатый киль на задней поверхности хелицеры и 2 зубца переднего края желобка хелицер; 41 - лапка I; 42 — лапка-предлапка I, пролатерально.

Обозначения: $F s$ - фильтрующие щетинки; $F h$ - перовидные волоски; $S k$ - зубчатый киль. 

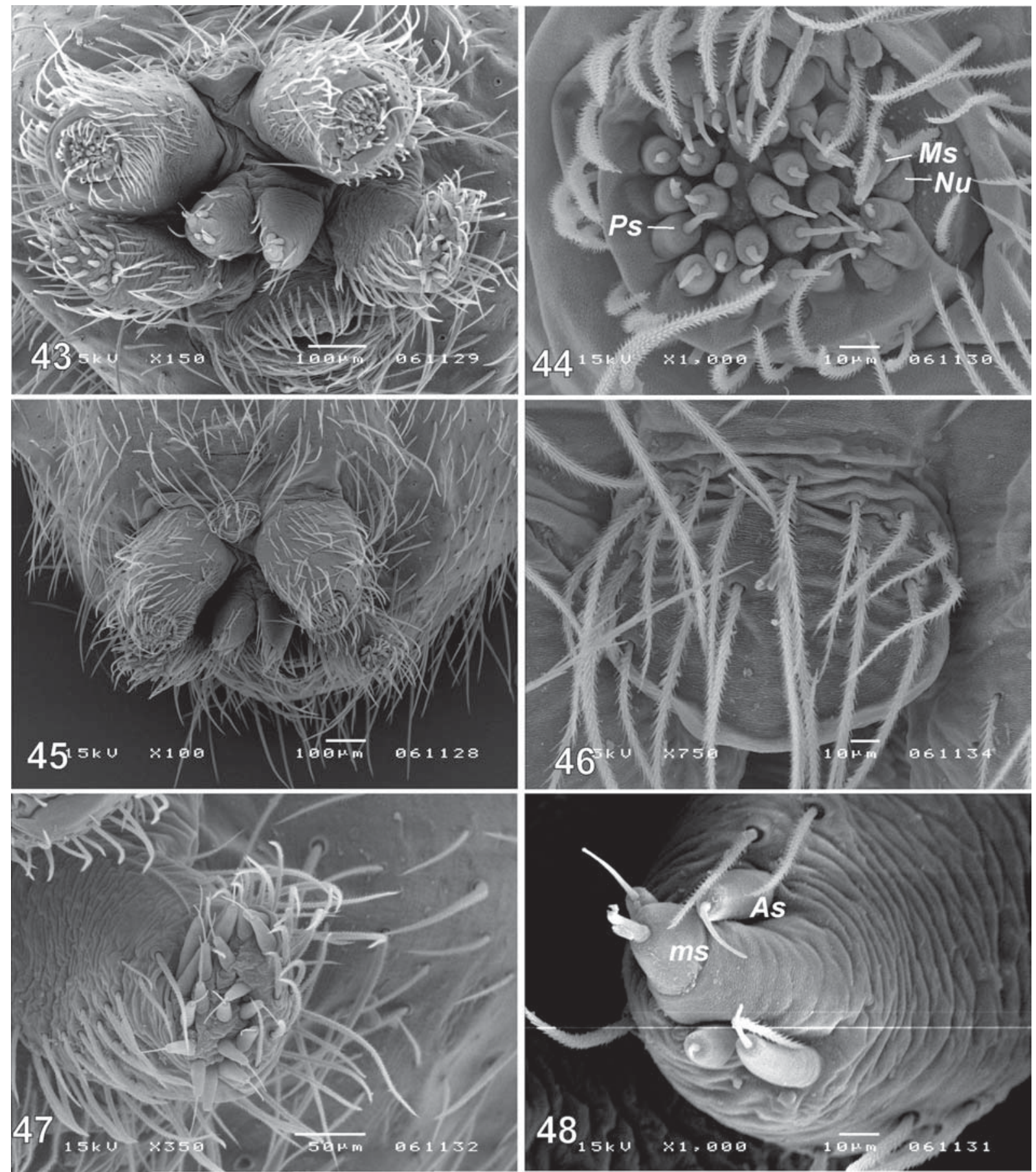

Figs 43-48. SEM micgrorgraphs of the spinnerets and colulus in Ovtchinnikovia caucasica sp.n.

Male: 43, 45 - all spinnerets, colulus and anal tubercle, caudal and ventro-caudal; 44 - anterior lateral spinneret; 46 colulus; 47 - posterior lateral spinneret; 48 - posterior median spinneret.

Abbreviations: $A s$ - aciniform gland spigot; $M s$ - major ampullate gland spigot; $m s$ - minor (?) ampullate spigot; $N u$ nubbin; $P S$ - piriform gland spigot.

Рис. 43-48. СЭМ-фотографии паутинных бородавок и колюлюса самца Ovtchinnikovia caucasica sp.n.: 43, 45 — паутинные бородавки, колюлюс и анальный бугорок в целом, сзади и сзади-снизу; 44 - передне-боковая бородавка; 46 — колюлюс; 47 задне-боковая бородавка; 48 - задне-средняя бородавка.

Обозначения: $A s$ - гроздевидная железа; $M s$ - большая ампуловидная железа; $m s$ — малая (?) ампуловидная железа; $N u-$ вырост основания большой ампуловидной железы; $P S$ - грушевидная железа. 
Palp as in Figs 10-13, 20-34. Femur unmodified, as long as cymbium. Patella unmodified, slightly longer than tibia. Tibia distally expanded with two apophyses: retroventral $(R v)$ and retrolateral $(T a)$. Retroventral apophysis complicated (Figs 10, 22, 33), consisting of digitiform process $(D p)$ and rounded lobe $(R l)$ (Fig. 33). Retrolateral apophysis subequal in length to tibia, turned ventrally, resembling a swan's neck and head, terminal part expanded, resembles head of swan or goose. Cymbium droplet-shaped, extended over bulbus, with basal retrolateral "fold" $(R f)$ (Fig. 33). Bulbus elongate with many processes. Tegulum with triangular retrolateral outgrowth $(T o)$, median (=tegular) apophysis $(M a)$ very long, located on prolateral side of tegulum. Conductor $(\mathrm{Co})$ large, with expanded terminal part. Embolic part $(E p)$ complicated, with bent embolus proper $(E m)$, thin filamentous tip $(E f)$, and two radical apophyses. Basal retrolateral apophysis $(R b)$ long and sharply pointed with spine-like outgrowth (So), basal radical_apophysis well visible in ventral and retrolateral view. Terminal apophysis $(T e)$ smaller than basal, partly hidden by conductor and embolus proper, its tip sharply pointed and turned.

Female. Total length 7.0. Carapace $3.1(2.7-3.5)$ long, 2.3 wide. Abdomen 4.3 long, 2.7 wide. Coloration (Figs 1, 3-4) as in male. AME 0.08, ALE 0.16, PME 0.14, PLE 0.15, AME-AME 0.08, AME-ALE 0.06, AME-PM E 0.12, ALE-PLE 0.05; PME-PME 0.16 ; PME-PLE 0.15. Eyes form much less compact group than in male (cf. Figs 16 \& 17). Palp with toothed claw (Fig. 5). Chelicerae as in male.

Leg joint length

\begin{tabular}{|l|c|c|c|c|c|c|}
\hline leg & Femur & Patella & Tibia & Metatarsus & Tarsus & Total \\
\hline I & 2.7 & 1.1 & 2.3 & 2.0 & 1.3 & 9.4 \\
\hline II & 2.5 & 1.1 & 2.0 & 1.9 & 1.2 & 8.7 \\
\hline III & 2.4 & 1.0 & 1.7 & 2.0 & 1.1 & 8.2 \\
\hline IV & 2.9 & 1.1 & 2.5 & 2.7 & 1.3 & 10.5 \\
\hline
\end{tabular}

Leg spination

\begin{tabular}{|c|c|c|c|c|}
\hline Leg & Femur & Patella & Tibia & Metatarsus \\
\hline I & $\begin{array}{c}\mathrm{d} 1, \mathrm{p} 1-1, \\
\mathrm{r} 1-1\end{array}$ & 0 & $\begin{array}{c}\text { p 1-1, r } 1, \\
\text { v 2-2-2a }\end{array}$ & v 2-2-3a \\
\hline II & $\begin{array}{l}\text { d 1-1, p 1-1, } \\
\text { r 1-1-1 }\end{array}$ & 0 & $\begin{array}{c}\text { p 1-1, r 1-1, } \\
\text { v 2-2-2a }\end{array}$ & $\begin{array}{l}\text { p 1-1, r 1-1, } \\
\text { v 2-2-3a }\end{array}$ \\
\hline III & $\begin{array}{c}\text { d 1-1, p 1-1-1, } \\
\text { r 1-1-1 }\end{array}$ & 0 & $\begin{array}{l}\mathrm{d} 1, \mathrm{p} 1-1-1, \\
\mathrm{r} 1-1, \mathrm{v} 2-2-2 \mathrm{a}\end{array}$ & $\begin{array}{l}\text { p 1-2-2, } \\
\text { r 1-1-2, } \\
\text { v 2-2-1a }\end{array}$ \\
\hline IV & $\begin{array}{l}\text { d 1-1-1, } \\
\text { p 1-1-1, r } 1\end{array}$ & 0 & $\begin{array}{l}\text { d 1, p 1-1-1, } \\
\text { r 1-1-1, } \\
\text { v 2-2-2a }\end{array}$ & $\begin{array}{l}\text { p 1-2-2, } \\
\text { r 1-1-2, } \\
\text { v 2-2-1a }\end{array}$ \\
\hline
\end{tabular}

Epigyne as in Figs 7-9, 14-15, undivided plate without any furrows or fovea, with translucent pair of receptaculae. Upper part of plate with transverse furrows. Copulatory opening placed in posterior wall of the plate, and hidden by the epigastric fold. Posterior wall of epigyne with small depression with two separate openings leading to very short insemination ducts. Lateral epigynal teeth lacking. Receptaculae round, each with accessorial gland opening on the dorsal side.

PHENOLOGY. Phenology was studied by mean of pitfall trapping in Taxus-Buxus grove in environs of

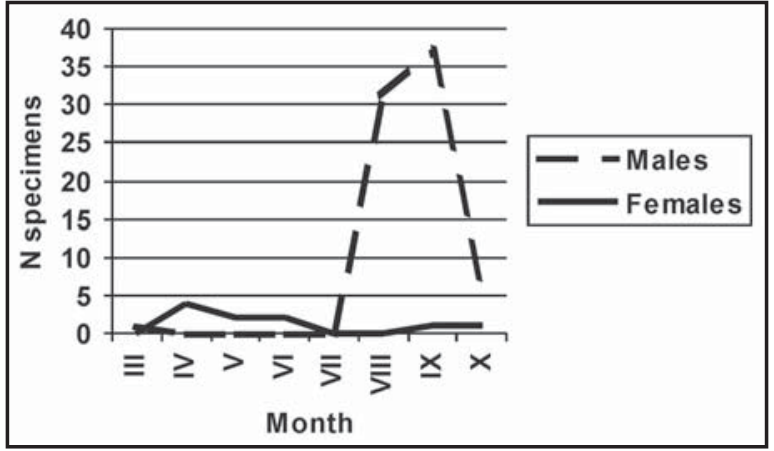

Fig. 49. Phenology of Ovtchinnikovia caucasica sp.n. in yewbox (Taxus-Buxus) grove.

Рис. 49. Фенология Ovtchinnikovia caucasica sp.n. в тиссосамшитовом (Taxus-Buxus) лесу.

Khosta Town. Adult females were found in April-July and in September-October only (Fig. 49). Activity of females was rather low. The maximal point was 0.13 specimens per 10 pitfall-trapping days. Such activity was observed only in April. During other month only single females have been collected. Males have been trapped in March and in August-October. Judging from high activity of males in August-September (1.23 specimens per 10 trapping days) it seems that mating take place at that period. Most of males die after copulation and only low percentage of them can survive until early spring. Adult females overwinter. Females produce eggs in April-June and then die.

DISTRIBUTION. The new species is known from two localities only, from Krasnaya Polyana and adjacent Caucasian State Biosphere Reserve (yew-box grove in environs of Khosta Town).

ACKNOWLEDGEMENTS. We thank J. Wunderlich, P.T. Lehtinen, J.A. Miller and late S.V. Ovtchinnikov for the discussion about possible position of the new genus. We also thank Seppo Koponen who arranged the visits of YM in Turku and allowed to use local facilities (SEM and digital camera attached to microscope). Material used in this study was provided to us by Y.A. Chumachenko (Maykop, Caucasian State Biosphere Reserve).

This work was supported in part by the RFFI grants \#\# 09-04-01365 and 09-04-90900 and also partly by the Karadagh Nature Reserve.

\section{References}

Griswold C.E., Ramírez M.J., Coddington J.A., Platnick N.I. 2005. Atlas of phylogenetic data for entelegyne spiders (Araneae: Araneomorphae: Entelegynae) with comments on their phylogeny // Proc. Calif. Acad. Sci. Vol.56. Suppl.2. 324 pp.

Jocque R., Dippenaar-Schoeman A.S. 2006. Spider Families of the World. Tervuren: Musée Royal de 1'Afrique Central. 336 pp.

Lehtinen P.T. 1967. Classification of the cribellate spiders and some allied families, with notes on the evolution of the suborder Araneomorpha // Ann. zool. fenn. Vol.4. P.199-468.

Miller J.A., Carmichael A., Ramírez M.J., Spagna J.C., Haddad C.R., Rezac M., Johannesen J., Kral J., Wang X.-P., Griswold C.E. 2010. Phylogeny of entelegyne spiders: Affinities of the 
family Penestomidae (new rank), generic phylogeny of Eresidae, and asymmetric rates of change in spinning organ evolution (Araneae, Araneoidea, Entelegynae). Molecular Phylogenetics and Evolution. Online supplementary documents. doi:10.1016/j.ympev.2010.02.021.

Nishikawa Y. 2009. A new genus and 44 new species of the family Coelotidae (Arachnidae, Araneae) from Japan // Ono H. (ed.). The Spiders of Japan with keys to the families and genera and illustrations of the species. Kanagawa: Tokai Univ. Press. P.51-70.

Platnick N.I. 2010. The World Spider Catalog, Version 10.5. American Museum of Natural History, New York. Online at http:// research.amnh.org/iz/spiders/catalog/ (accessed November 1, 2010).

Ponomarev A.V., Chumachenko Yu.A. 2007. [Arachnids (Arachnida) in epigean mesofauna of the yew-box grove in the Caucasian Biosphere Reserve] // Trudy Yuzhnogo Nauchnogo Tsentra RAN. T.3. Bioraznoobrazie i transformatsia gornykh ekosistem Kavkaza. P.151-163 [in Russian]

Wang X.P. 2010. Online Coelotinae, version 2.0. Online at http:// www.amaurobiidae.com (accessed November 1, 2010).

Responsible editor S. Koponen 